\title{
CASH MANAGEMENT: HOW DO COUNTRIES PERFORM SOUND PRACTICES?
}

DOI: $10.22458 /$ rna.v12i1.3572

\author{
M. Coskun Cangoz ${ }^{1}$ \\ Leandro Secunho ${ }^{2}$
}

1. Manager, World Bank Treasury, 1818 H Street, NW Washington, DC 20433 USA, cangoz@gmail.com,

https://blogs.worldbank.org/team/m-coskun-cangoz

2. Senior Debt Specialist, Macroeconomics, Trade and Investment (MTI), 1818 H Street, NW Washington, DC 20433 USA,

lpuccinisecunho@,worldbank.org, https://orcid.org/0000-0002-2142-668X

\begin{abstract}
Cash management is simply defined as making the right amount of money available at the right time and the right place to meet the government's obligations in the most cost-effective way. The main features of modern cash management are centralized government bank accounts and establishment of a Treasury Single Account, ability to make accurate cash flow forecasts, use of short-term financing instruments, and capacity for the investment of excess cash reserves. Establishing a sound cash management framework with the mentioned features is beneficial not only to the governments and public entities, but also to other stakeholders including the beneficiaries of government payments, banks and lenders. Given the recent COVID-19 (coronavirus) pandemic and lockeddown measures introduced in many countries, governments had to deal with unanticipated revenue decreases, and significantly increased public expenditures due to fiscal stimulus packages and pandemic related health expenditures. Therefore, existence of a well-structured government cash management is now even more important than before. This paper aims to explore cash flow forecasting and cash management practices in 24 countries in various regions, at different income levels and technical capacity, and alignment to good practices based on the information provided at the World Bank workshops on Cash Flow Forecasting and Cash Management held in 2018 and 2019. The paper also draws on experiences and practices from other emerging and advanced countries. Cases from different countries indicate that full implementation of modern cash management is still a challenge, even though the Treasury Single Account system is common in most countries and liquidity buffers were established or increased following the Global Financial Crisis. Cash flow forecasting is an area to improve given the accuracy, horizon and frequency of the projections are frequently limited. Fragmented institutional structure makes cash management even more challenging. Country cases also demonstrate that there is a significant room to strengthen coordination between debt and cash management and the use of short-term instruments to cover cash shortages. Investment of cash balances seems to be a bigger weakness as many countries keep their liquidity buffers in the Central Bank with no remuneration.
\end{abstract}




\section{CASH FLOW FORECASTING}

Cash management is a process which aims at making the right amount of money available at the right time in the right place to execute the government's payment obligations. This widely accepted definition seems simple but putting it into practice might be challenging. In case the full amount (right amount) is not transferred, at the required time (right time) to the beneficiary (right place) the government can face with payment arrears and default. This three-legged process can be called as "calibration of 3 Rs" where each R represents a "right" for the amount, the place and the time. Finding the "right" balance of 3 Rs is like three-ball juggling, and none of the balls should drop anytime. Therefore, it requires a strong cash flow forecasting capacity and the ability to implement cash flow projections.

The main objective of cash management is to minimize gaps between cash inflows and outflows at any point of time, ideally in the next 3 months. To this end, in order to determine the "right amount" for the required payments, cash managers need to project expected revenues and payments, and identify the gaps.

\section{Governance and Institutional Framework of Cash Flow Forecasting}

Cash flow forecasting is key to ensure that government's payment obligations are fully met, and arrears are not accumulated. However, if cash management is not well-positioned in the government's planning and resource management cycle and has weak linkages with debt management, a cash manager will not be able to produce accurate projections of cashflows and cannot provide reliable and timely information to decision-makers, spending agencies, Central Bank and markets. Therefore, as confirmed by sound practices, setting appropriate institutional arrangements and identifying the responsibilities across institutions are essential for effective cash management.

Cash management, as an element of strong public financial management, helps keeping payments within the budget limits, through authorized budget allocations. It can further improve realism of fiscal projections and assist decision-makers to identify corrective fiscal actions. However, cash management is not part of the budget cycle and not a tool to maintain fiscal control.

Some countries consider cash management as a part of budget management and position it either entirely (Chile) or only some of its functions (Ghana, Seychelles) within the Budget Department. Besides, some countries carry over cash management fully or partially in the Accountant General's Office (Eswatini, Lesotho, Nigeria). There are also cases where cash flows are projected by other departments (e.g. Macroeconomic Policy Analysis Unit of The Gambia).

\section{Figure 1}

Principal entities in charge of cash management in workshops' participating countries

As shown in Figure 2, in most of the assessed countries, cash management is a function of the Treasury and

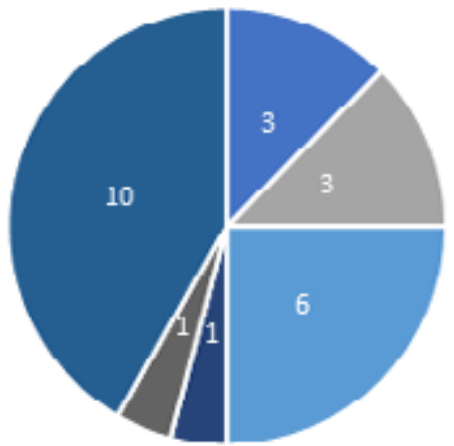

- Acc. Gen. Office = Budget Dept = $\quad$ Cash Mng Unit

- Other - DMO $\quad$-Treasury 
positioned either as a dedicated unit (South Africa, Kosovo, Rwanda) or dispersed across divisions. It is also widely reported that cash and debt management functions are integrated (Colombia, Kosovo, Peru, Romania, Slovenia, South Africa and Thailand). This is indeed parallel to the practices in advanced countries, as demonstrated by a recent survey that integrated cash and debt management is a common practice across the OECD countries (Cruz and Koc, 2018). On the other hand, there is no specific solution which fits all countries. Therefore, institutional arrangements may vary across countries as long as main features of effective cash management are secured. Clear definition of responsibilities and workflows within and among the entities in charge of cash management, well-organized internal controls and existence of analytical capacity indicate that "appropriate institutional arrangements and responsibilities" are in place as defined by Lienert (2009).

Regardless of the reporting lines, a Treasury Single Account (TSA), where all the government revenues are collected and payments are made, is the main source of actual data for cash managers. TSA is the common practice across countries. Parallel to the general practices, in all countries discussed in this paper, if the TSA is in place, it is in the Central Bank and the main account is in local currency, even when there are TSA subaccount in foreign currency. Countries such as Lesotho and Nigeria recognized the TSA's pivotal role in cash management and recently established their TSA systems. There are only a few countries that do not have yet a system for a centralized bank account (e.g. Equatorial Guinea) due to, among other reasons, limited capillarity of central bank branches and insufficient payment and process systems. Gradual implementation of a TSA "system" by consolidating government funds in fewer accounts, respecting existing country limitation is advisable.

In a case where cash management functions are fragmented, coordination becomes more challenging and inefficiencies in organizational arrangements may lead to less accurate cash flow projections. In order to overcome the deficiencies in coordination, many countries have established high and/or technical level committees (Bolivia, Chile, Ghana, North Macedonia, Romania, Gambia and Rwanda).

\section{A. Cash Flow Forecasting Practices}

In the absence of cash flow forecasting and planning, governments mostly make the payments in line with the priorities of the political economy, if there is not a sufficiently large cash balance. In such cases, inefficient allocation of financial resources may result in over or under borrowing that can also lead to increased costs and risks. On the other hand, in cases where comprehensive and accurate cash flow forecasting is in place, cash management ensures required funds are transferred to the beneficiary's account at the right time. Along with the methodology applied to forecasting cash flows, the coverage, time horizon and frequency of forecasts are also critical to find the right balance of 3 Rs.

The Government's budget is an output of broader national policy processes and includes directives and limits for the collection and allocation of public resources. The strategic budgeting phase involves government institutions such as finance and planning ministries, sector ministries, large spending agencies and other entities like the civil society groups. Based on the strategic directions set at the policy level, budget officials prepare the formal budget which includes estimated revenues and expenditures for each budget entity. Considering that the government budget provides information on the size of the revenues and expenditures and about the public entities entitled for these transactions, as the first step, a cash manager produces an annual cash flow plan based on the budget. This process is simply an application of a top-down approach: (i) review aggregate budget figures (ii) conversion of data from budget to cash-base, (iii) generation of monthly, weekly and daily cash flow forecast with application of analytical models on the historical TSA data, (iv) incorporation of possible changes in government policy and regulations which may affect the collection of revenues and use of public resources, (v) addition of contingencies (Figure 2). 


\section{Figure 2}

Cash Flow Forecasting Approaches: Top-down vs. bottom-up

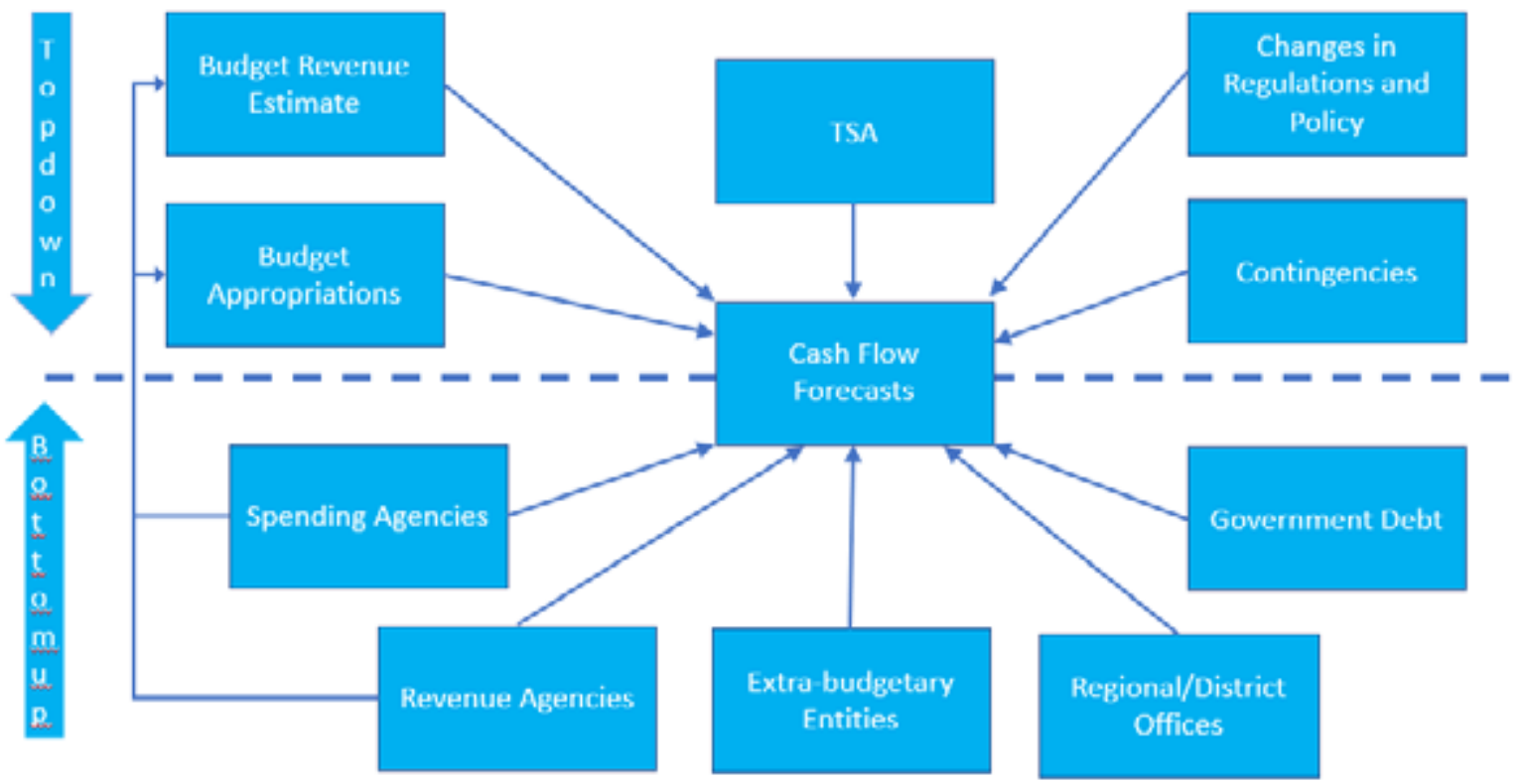

Source: Authors.

The main output of cash flow forecasting is accurate daily forecasts for at least one month ahead, preferably for the next three months. However, the granularity of the budget data and their frequency do not allow the cash manager to determine the exact time of cash inflows and required time of the payments. Therefore, in order to find the right balance of 3 Rs and produce reliable forecasts, cash managers combine the top-down approach with a bottom-up approach.

\section{Coverage of cash flow forecasts}

Cash management is part of the public financial management process and directly affected by the effectiveness of budget planning and execution. In principle, expected revenues and expenditure ceilings of central government agencies set in the government budget are the main inputs of cash flow forecasting. On the other hand, it is a fact that in many countries, in particular in the developing and emerging countries, the coverage of state budget could be limited, because public funds are utilized through extrabudgetary funds (e.g. Vietnam ${ }^{1}$ ) and/or earmarked accounts (e.g. Ghana, South Africa ${ }^{2}$ ). However, in case that these entities/accounts collect and spend public resources through Treasury bank accounts, they should be included in the cash flow forecasts even if they are not covered by the budget.

The scope of the TSA is critical to determine the coverage of cash flow forecasts and cash management, which is the central government in most countries. However, depending on the decentralization of government, and the compliance of accounting and control systems, the scope of cash management (and of the TSA) can be extended from central government to general government level (e.g. France).

Contingent liabilities, such as loan guarantees and commitments of public-private-partnership contracts, are classified as off-budget items. These liabilities are monitored by most countries, and paid by the government, when called. In order to avoid any default due to unanticipated payments, potential calls from the contingent liabilities should be included in the cash flow forecasts.

1 IMF Fiscal Monitor, April 2020.

2 Cashin, C., S. Sparkes and D. Bloom (2017). 


\section{Horizon and frequency of forecasts}

Multi-year budgets have become more common and may provide a longer-term horizon for cash flow projections. However, even for the countries with multi-year budgets, the annual budget that is formally approved by parliament, is still the key document. Accordingly, with some exceptions, the horizon of cash flow forecasts is not going beyond one year. On top of budget estimations, cash flow forecasting and cash management are affected by a number of factors such as the means of payments (e.g. cash, cheque, electronic payments), the payment agents (e.g. Central Bank, commercial banks), the cash management capacity of central government and local government institutions, and the depth and liquidity of government bond and money markets (Miller and Hadley, 2016). Therefore, both horizon and frequency of cash flow projections rely on different parameters and show significant variances across countries. There are countries (e.g. South Africa, Albania) preparing cash flow forecasts for 3-years, yearly, monthly, weekly and daily periods, but on the other side, there are cases where only monthly cash flow forecasts are in place (e.g. Angola, Nigeria). Most of the countries are preparing yearly cash flow projections with different frequencies such as monthly (Kosovo) weekly (Seychelles) and daily projections (Bolivia, Colombia, Honduras, North Macedonia, Uruguay). In parallel, the periodicity of the revisions of cash flow forecasts differs across countries. In most cases the projections are reviewed and revised weekly or daily. However, there are countries revising the forecasts just monthly.

\section{Box 1. Extensive Cash Flow Forecasting: South Africa}

Extended cash flow forecasting enables South Africa to ensure that government manages its cashflow to have sufficient cash to meet its obligations; to neutralize the impact of government's cash flows in the liquidity of the financial system; and to maximize returns on surplus cash. One of the objectives of extended cash flow projections is to ensure there are no large and unpredictable changes in liquidity in the banking system and monetary policy is not undermined.

\begin{tabular}{|c|c|c|c|}
\hline \multirow{5}{*}{$\begin{array}{l}\text { E } \\
\frac{5}{6} \\
\text { 믕 } \\
\text { 옹 }\end{array}$} & 3-year annual forecast & & \\
\hline & Year 1 & Year 2 & Year 3 \\
\hline & $\begin{array}{c}\text { Months } \\
123456789101112\end{array}$ & $\begin{array}{c}\text { Months } \\
123456789101112\end{array}$ & $\begin{array}{c}\text { Months } \\
123456789101112\end{array}$ \\
\hline & \multicolumn{3}{|c|}{ Current year rolling monthly forecast } \\
\hline & $\begin{array}{c}\text { Year 1 } \\
\text { Months } \\
123456789101112\end{array}$ & \multicolumn{2}{|c|}{.... Rolling into year two } \\
\hline \multirow{3}{*}{$\frac{\text { E }}{\frac{5}{\grave{ }}}$} & \multicolumn{3}{|c|}{ 90-day daily forecasts (or longer if needed) } \\
\hline & $\begin{array}{l}\text { Days } \\
1-90\end{array}$ & & \\
\hline & \multicolumn{3}{|c|}{ Current day firm forecasts (11:00 and 15:00) } \\
\hline
\end{tabular}

Source: National Treasury

In the cash flow projections, National Treasury forecasts revenues, expenditures, domestic and external debt redemptions, financing of borrowing requirements and the resulting change in cash balances for 3 years with different frequencies, as shown in the figure above. 
The Debt Management Performance Assessment (DeMPA) tool of the World Bank evaluates the reliability, horizon and frequency of cash flow forecasting, through Debt Management Performance Indicator (DPI) $11.1^{3}$, which requires monthly forecasts for getting Score C, weekly breakdowns for score B and daily estimates for Score A, the highest. As of end-2019, DeMPA assessments have been implemented in 80 developing countries, and only 28 percent of them met the minimum requirement or above (Figure 4, blue bars).

\section{Figure 3}

Share of DeMPA assessed countries that reached minimum requirement (score $C$ or above)

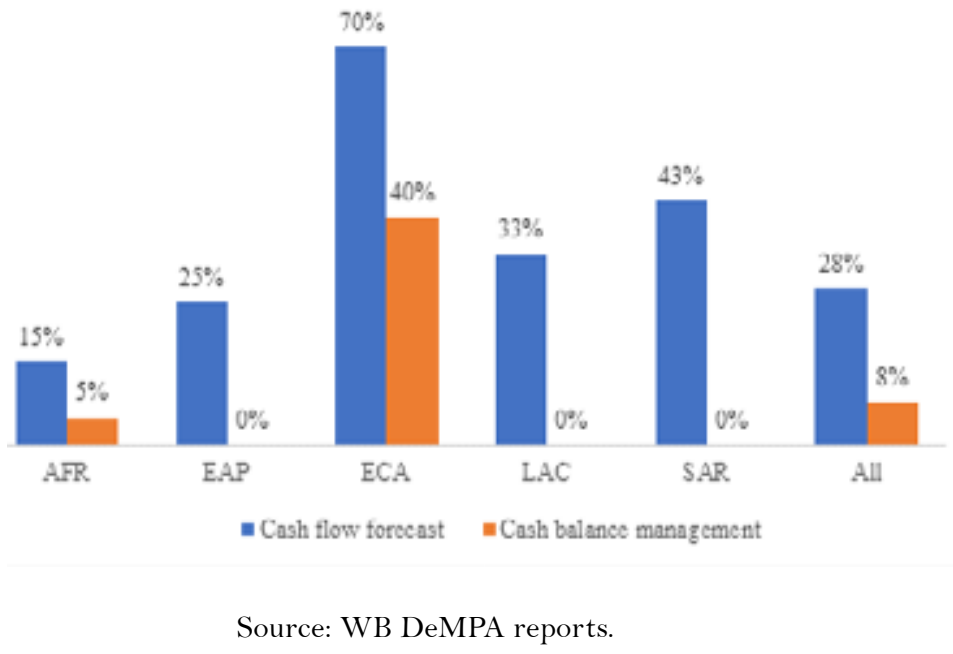

As prescribed by DeMPA methodology, countries should ideally prepare daily cash flow forecasts, but even when the breakdown of the estimates is monthly (minimum requirement), it is advised to cover the budget year (horizon). On the other hand, given the budget figures may not be available yet closer to the end of the fiscal year, cash managers should have the capacity to estimate the cash-flows for the initial months of the following budget year.

\section{Revenue forecasting}

It is the common practice to forecast revenues through the application of a top-down approach considering that (i) main tax items (e.g. income tax, corporate tax and V.A.T.) and customs' tax and duties comprise the significant part of total collections, which for good estimates is provided by the annual budget's tax projections, (ii) revenues have strong seasonality and it is practical to generate monthly and weekly breakdowns from annual budget figures by using historical data, and (iii) it captures necessary adjustments due to the changes in government policy and regulation, macroeconomic and financial developments. Accordingly, in most countries, cash managers rely on the projections of the tax administration. On the other hand, there are cases where revenues are projected by the cash management unit (Peru), the fiscal policy office (Thailand), or the macroeconomic forecasting unit (Seychelles).

For the revenues other than tax and customs, such as dividends, grants and receivables from on-lent loans, the best way to produce forecasts is to apply bottom-up approach which refers to the collection of information from relevant institutions as the granularity is not the same and individual flows can be followed. 


\section{Expenditure forecasting}

Given that the government budget imposes expenditure ceilings through appropriations, and the nature of nondiscretionary expenditures is quite predictable, cash managers are relatively more comfortable for expenditure forecast. However, considering the time lags between the release of appropriations and actual payments from the TSA, cash managers tend to rely more on the historical TSA data in the expenditure forecasts. Besides, historical data, and the laws and regulations may also provide useful information on the payment dates of regular and large transactions.

Discretionary expenditures (e.g. goods and services, capital expenditures, subsidies and transfers) are prone to government policy decisions that makes them harder to forecast. Therefore, it would be more efficient to concentrate on major projects and programs which require large payments, rather than aiming to forecast all expenditures. On the other hand, in most countries, linked to the budget appropriation's release calendar and due to the budget's spend-it-or-loose-it policy, discretionary expenditures, in particular the goods services and capital expenditures, show a strong seasonality due to the weak performance at the beginning of the year and, on contrary, high spending in the last few months.

Due to the fact that cash managers cannot know the physical conditions of the infrastructure investments and are not able to assess the best time the goods and services are needed, sector-ministries and spending agencies are the best resources to provide information for the projection of discretionary expenditures which refers to a bottom-up approach.

Although the quantitative analysis and spending agencies' inputs are at the core of expenditure forecasting, qualitative judgments contain additional information that cannot be incorporated into the models. They allow cash managers to adjust forecasts considering the reliability of data collected from different sources and the counterparts' forecasting performance.

\section{Incorporating debt data}

Debt interest and principal payments are significant elements of cash flow forecasts, along with the cash inflows from the issuance of new debt. It is a common practice that debt managers provide cash flow projections related to debt service and borrowing. In addition, cash managers commonly coordinate with debt management office to collect information on the contingent liabilities, in case they may materialize.

Cash flow forecasts associated to floating, inflation-linked, foreign-currency denominated or any other variable debt need to be estimated using macroeconomic scenario(s) that not necessarily (or commonly) are produced by debt managers (a third party usually generates the required estimates, e.g. Central Bank or macro unit at MoF). Shock scenarios can be useful when defining a liquidity buffer policy, as it is also the case on the design of a Medium-Term Debt Management Strategy (MTDS).

\section{Accuracy of forecasts}

Producing reliable and accurate cash flow forecasts is crucial for public financial management policy setting and implementation through (i) providing critical information to decision making to take corrective fiscal actions, (ii) avoiding accumulation of arrears and (iii) minimizing cost of carry.

There are factors that create deviations between the initial forecasts and actual figures, such as external events, change in government policy, or lack of information. In order to eliminate some of these factors and improve accuracy of cash flow forecasts, countries introduce monitoring mechanisms and preventive actions. Real time monitoring of TSA balance allows cash managers to assess the performance of cash flow forecasts, but strong electronic banking/payment infrastructure is a prerequisite. More realistic budget projections, sensitizing the line ministries on the cost of forecasting errors and mitigation measures such as developing more coercive framework to prevent unexpected large payments help improve accuracy of forecasts. 
Forecasting deviations from actual cash flows should be frequently reviewed in order to improve the accuracy of the projections and help cash managers understanding the sources of errors. To this end, it is useful to keep a repository of historical forecast data that enables granular analysis of the deviations throughout different periods of the year and time lags between estimated and realized cash flows. Just 9 out of the 24 workshop participating countries presented numbers of the accuracy of their forecasts, indicating that thorough assessment of estimates performance has not been extensively done in most of these countries and pointing out to a possible area for improvement.

A liquidity buffer, discussed in detail in Section III, is a useful tool to deal with deviations between the projections and realizations.

\section{FINANCING CASH FLOW GAPS}

Cash balance management encompasses two main tasks: i) raising funds to cover cash shortages; and ii) investing cash balances to minimize the cost of carry. The government will float from one side to the other depending on its current and expected cash balances (shortage or excess), and the cash flow forecasting underpins both tasks. One may argue that the main connection between cash and debt management can be seen on the use of short-term instruments to cover temporary lack of cash, which is true. Nonetheless, it is worth noting that investing cash will just make sense when government is not borrowing, given the cost of carry.

The choice of instruments to be used to cover temporary cash shortages is dependent on the expected period for the cash imbalance and associated costs. The chart below shows the funding instruments used by governments for cash and debt management, while demonstrates how T-bills and the liquidity buffer stand in the intersection and well serving both activities ${ }^{4}$.

\section{Figure 4}

Funding instruments for cash and debt management

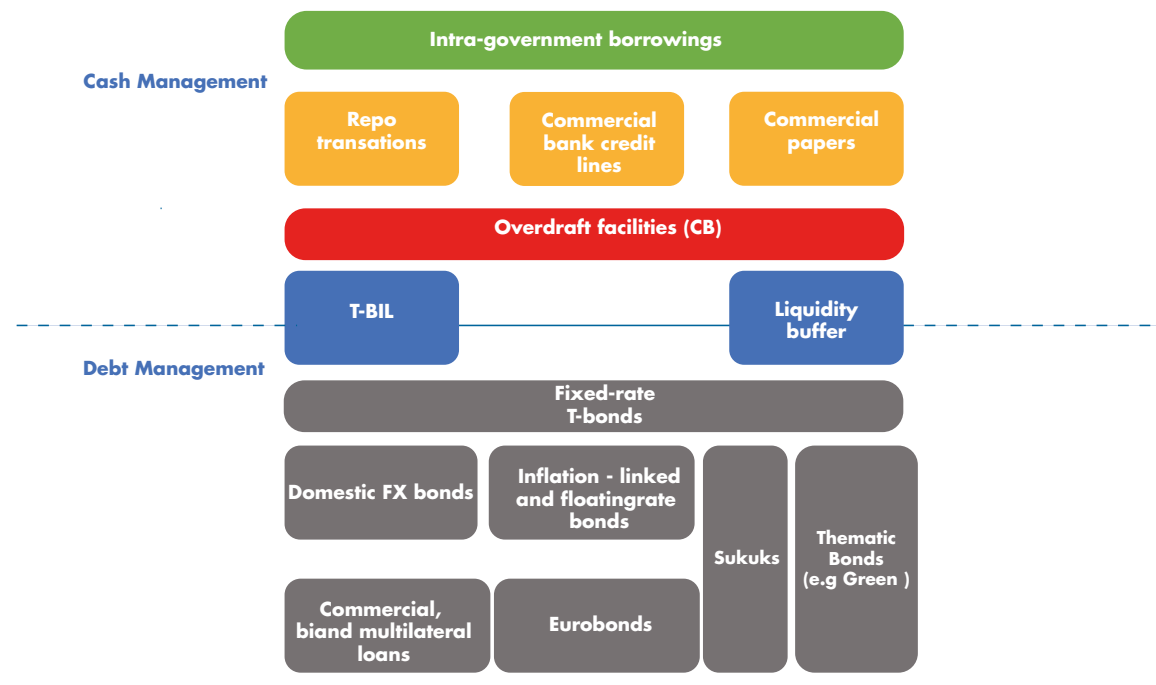

Source: Authors.

4 Commercial papers may also be used for debt management, although are more commonly applied to solve short-term cash imbalances (cash management). 


\section{A. Funding Instruments}

Temporary cash shortages can be covered by cash managers through a variety of instruments illustrated in Figure 4 and explained in the following:

Overdraft facility: The Central Bank provides a short-term credit line (also referred as advances) usually with volume and time caps (used, for instance, by Eswatini, India and Uruguay). Many developing and developed countries has limited this practice to avoid inflationary and foreign currency spillover effects due to the financing of central government by the monetary authority (Brazil and Chile banned any Central Bank financing at the constitutional level). However, more recently, monetary financing has been extraordinarily used by several countries under less constrained framework than what it ideally should $b^{5}{ }^{5}$, due to the governments' increasing cash needs resulted from the COVID-19 crisis (see Box 4). When available to the government, the overdraft facility tends to be one of the most flexible instruments, but with possible drawbacks in terms of cost and volume cap

\section{Box 2: Central bank financing to governments}

While monetary and fiscal policies bring undeniable interlinkages, separation between Central Bank mandate and government financing needs to be in place to avoid undesirable interferences on the implementation of each policies and support fiscal discipline.

Jácome et. al. (2012) show that in a sample of 152 countries, 57 permit the use of advances, while 40 allow the use of credit (loans) and 51 set prohibition to any kind of credit. Results from DeMPA assessments carried out in 80 countries as of end of 2019 also point out the need of narrowing the conditions in which government can directly borrow from the monetary authority.
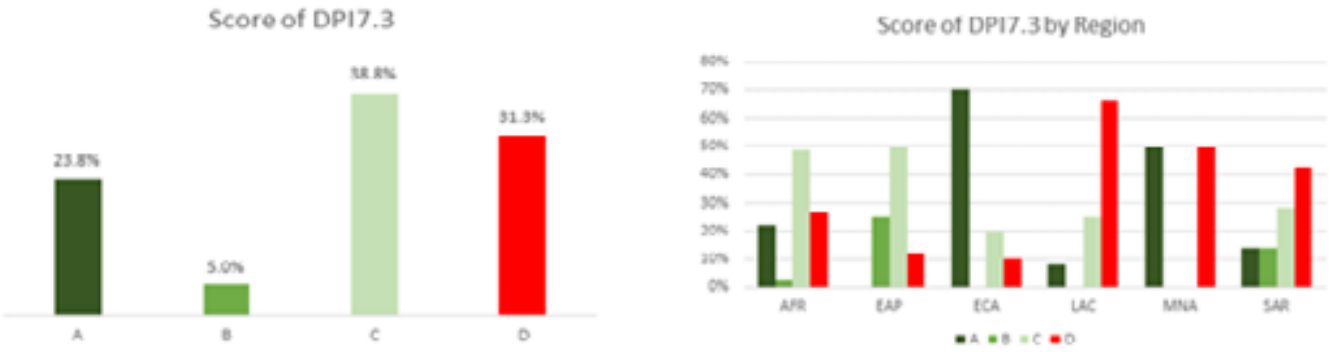

Almost one third of the assessed countries don't impose a legal ceiling for direct borrowing from the Central Bank (score D), which is the minimum requirement for score $\mathrm{C}$ under DeMPA. On the other hand, slightly less than one fourth of the countries legally prohibit or limit the monetary financing to emergency situations and to periods not longer than two weeks (score A). Besides, the approaches significantly vary across regions: majority of the countries in Latin-America does not get the minimum score, while more than two third of the European and Central Asian countries have obtained the highest score in the latest assessments.

As a response to the Global Financial Crisis, the Federal Reserve (USA), the Central Bank of Europe and the Bank of Japan have provided liquidity to the bonds holders (including banks and institutional investors) by purchasing government securities in the secondary market, to achieve financial markets' stability. In this case, the Central Banks' objective was not to support the coverage of short-term cash imbalances of governments, as targeted by the overdraft facilities. However, more recently, with the increased financing needs related to the COVID-19 pandemic, some countries have authorized Central Banks to finance governments directly through the purchase of government securities in the primary market, and to support the bond holders in the secondary market (See Arslan, Y, Drehmann, M and Hoffmann, B (2020)).

5 The WB Debt Management Performance Assessment (DeMPA) scores countries in its Development Policy Indicator - DPI 7.3 (Extent of the limit of direct access to financial resources from the Central Bank) according to the imposition of ceilings on the volumes and tenor, getting maximum score the countries who prohibit the direct financing or limit the advances to emergency situations for periods not longer than two weeks. Red color for the overdraft facilities in Figure 4 represents the emergency character of these instruments, ideally not used on regular basis for government financing. 


\section{Box 2: Central bank financing to governments: an emergency tool (Cont.)}

The Central Banks in Indonesia, Thailand and Malaysia have bought government securities in the primary market, while the monetary authority has been the buyer of the bonds in the secondary market in Chile, Colombia, Hungary, India, Israel, Korea, Mexico, Philippines, Poland, Romania, South Africa, Turkey and Malaysia (Brazil and Czech Republic requested amendment to the law to be able to do so). The Central Bank of Philippines has also recently established repo transactions between the Bank and the Bureau of the Treasury to cope with temporary cash imbalances associated to the crisis.

Source:https://dataviz.worldbank.org/views/FS-COVID19/

Overview?:embed=y\&:isGuestRedirectFromVizportal=y\&:display_ count $=$ n\&:showAppBanner $=$ false $\&$ :origin $=$ viz_share_link $\&:$ showVizHome $=\mathrm{n}$

Repo transactions: These transactions are defined as the temporary sale of a (government) security associated with the seller's commitment to purchase it back, after a pre-defined period and on a pre-agreed price. Governments use repos to cover temporary cash shortages by delivering a government security to the lender. Repos provide good flexibility and, in most cases, are used for periods not longer than the time span between T-bills auctions. Interest rates and tenors are negotiated by the counterparts, commonly under a Global Master Repurchase Agreement ${ }^{6}$. The advantage of these transactions for the lender is to receive a collateral (government security). Several countries use repo operations for temporary borrowing, including Hungary, France, Sweden, USA and UK. Despite of the usefulness of the repo transactions for cash management purposes, countries with less developed cash management practices and shallower money markets, mostly rely on the issue of T-bills for covering cash shortages. Finally, it is important to consider the way these transactions are captured in debt statistics to avoid underestimations that may affect monetary and fiscal policies and rules, given the repos can be used by treasuries to cover cash shortages, and by central banks for drying-up financial system liquidity.

Commercial banks credit lines: Unsecuritized direct borrowing from commercial banks under bilateral arrangements is an option for countries with less developed financial markets. This instrument is simpler, but typically costlier compared to securitized transactions. Commercial bank credit lines have a high degree of flexibility in terms of tenors, but they may be constrained by exposure limits to the government ${ }^{7}$ and there are some concerns about the instrument transparency. It tends to be used just for very short-term and emergency needs. Romania and Equatorial Guinea keep commercial bank credit lines in their menu of cash management tools.

Commercial papers: These money market instruments are usually issued by corporates and financial institutions to manage their cash position, for maturities up to one year, similarly to T-bills for governments. The main benefits are the standardization and depth of the large CP markets in the US and Europe. Issuances are done under a 'program' arranged with a few commercial banks, that reach out to investors. The program leaves the issuer with a lot of flexibility to issue when needed through tap issuances (private placements). CP programs are popular with European DMOs (including Austria, Belgium, Denmark, Ireland, Italy, Netherlands, Sweden), both in EUR and USD, as a way to diversify the investor base at the short end of the curve. It may also be used, in a smaller extent, for debt management.

Intra-government borrowing: Governments have been expanding their sources of short-term funding either through pooling government resources beyond the central government in the TSA, or by establishing specific borrowing mechanisms to access resources of local governments, state-owned enterprises and public funds. Intragovernment borrowing mechanism mitigates unnecessary government borrowing from the market by matching public entities that have cash shortages and cash surpluses. France TSA, held at Banque de France, is composed by approximately 5,000 government accounts including the Treasury Correspondents. In Portugal, the Credit Public and Treasury Management Institute (Instituto de Gestão da Tesouraria e do Crédito Público - IGCP) is authorized to

\footnotetext{
6 For further details see https://www.icmagroup.org/Regulatory-Policy-and-Market-Practice/repo-and-collateral-markets/ legal-documentation/global-master-repurchase-agreement-gmra/

7 Prudential regulations usually require that lenders allocate capital once the credit line is established, even if it is not used
} 
issue Special Certificates of Public Debt (CEDIC) as a mechanism for public sector corporations investing their excess of cash. South Africa TSA is held at South African Reserve Bank who outsources to its fully-owned subsidiary (Corporation for Public Deposits - CPD) the task of investing excess of cash. The resources to be invested come from the national government, provincial governments and state-owned corporations (SOCs).

T-bills: These are the zero-coupon securities with assumed maturities from weeks up to 1 year. As shown in Figure 4, T-bills are used both by cash and debt managers. For cash management purposes, T-bills may be issued under a flexible approach, not necessarily through regular issuances, offered amounts defined according to immediate cash needs and tenors determined by the length of the expected cash shortages ${ }^{8}$. On the other hand, T-bills are one of the main instruments for debt managers either to deal with debt cost-and-risk trade-off ${ }^{9}$ or cope with large financing needs in the absence of a diversified investor base (concentrated in commercial banks)

\section{III.LIQUIDITY BUFFERS AND MANAGING EXCESS CASH BALANCE}

The establishment of a liquidity buffer ${ }^{10}$, similarly to what was discussed for the T-bills, is part of cash and debt management policies (as reflected in Figure 4). It serves for the mitigation of risks that are mostly, but not solely,

\section{Box 3 - Defining the size of liquidity buffer}

The definition of the liquidity buffer size is not necessarily a function of a single parameter, but commonly a combination of more than one factor. Below are some examples on how countries define the size of liquidity buffer, based on an OECD survey undertaken in 2017 with 35 member countries, complemented by countries specific practices.

Albania - a liquidity buffer floor is defined by the average of expenditures of the three last days

Aspects to define cash buffer size (OECD Survey, 2017)

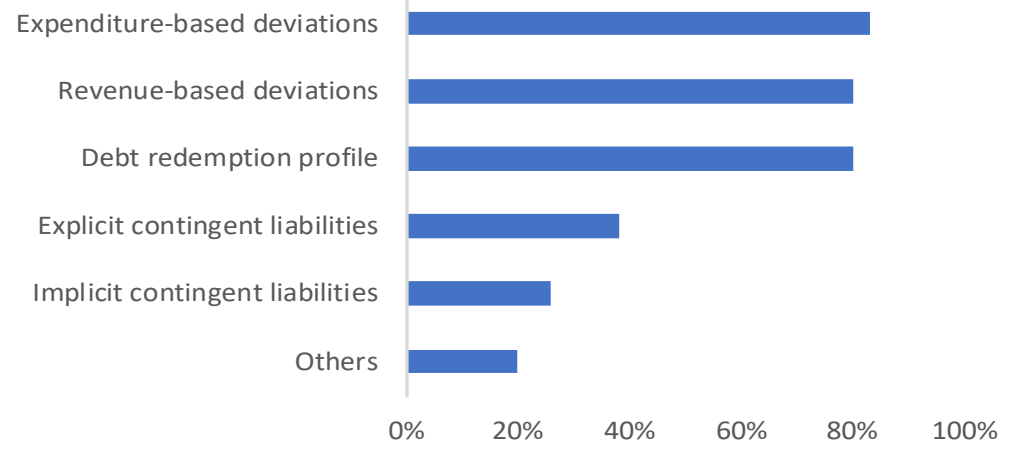

of the previous month (when outflows are concentrated), while the ceiling is determined by expected expenditures of the first week of the current month.

Brazil - an informal minimum cash balance is targeted aiming to cover 6 months of domestic debt refinancing needs. There is also a separate liquidity buffer for external debt (capped on the debt maturing in 1,500 days).

Ghana - minimum cash balance is (not formally) defined as a nominal number (roughly USD 170 million) based on the historical data of debt maturity profiles and above the line items.

Romania - no specific level for the liquidity buffer, but if cash is decided to be invested, a minimum (non-invested) balance is required (approximately EUR 200 million) during the investment period.

Thailand - minimum balance is required to cover at least 2 weeks of future expenditures.

8 Investors don't request the same level of predictability compared to longer-term instruments.

9 Even countries with wide access of long-term funding use T-Bills to shift the issuance and portfolio profile, temporarily shortening them to avoid excess cost when yield curve slope is uncommonly steep

Commonly also referred as cash cushion or cash buffer 
present in cash management (liquidity, operational, settlement and payment) and debt management (refinancing and related to market volatility). As the accumulation of large liquidity buffers mean increasing the cost of carry related to keeping these resources, there is a trade-off between the cost and the risks that are meant to be mitigated by the cash cushion. The cost of carry can be minimized by determining the size of required cash balance and investing the cash not for immediate use. There are different approaches across countries to determine the size of liquidity buffers (Box 7).

\section{Box 3 - Defining the size of liquidity buffer (Cont.)}

Turkey - minimum cash balance is determined as a percentage of the maturing debt in the coming months, and the level is calculated through considering (i) average demand decrease in the market (on volatile times); (ii) share of planned financing in stress periods; (iii) forecasted inflows and outflows for the year; and (iv) maturity profile of debt obligations.

Uruguay - cash buffer is determined as a range, where the minimum target is expected to cover the debt service under an extreme stress period (12 months without new issuance). Statistical calculations, based on the historical volatility of cash flows, are also considered to define the interval.

Sources: OECD WPDM 2017 Survey on Liquidity Buffer Practices, and country cases presented in the WB Cash Flow Forecasting and Cash Management Workshops (2018 and 2019).

\section{A. Minimizing the Cost of Carry}

Although active investment of excess cash in the market requires prior conditions, it does not mean that less developed countries which do not meet above-mentioned prerequisites are unable to reduce the cost of carry. To this end, the first possible action is refining the matching of cash inflows and outflows to reduce cash imbalances (including excess of cash). Different from cash rationing, this is an effort to smooth out cash balances by matching the calendars of expenditures payments and revenues receipts. This is a two-way avenue: defining large above-theline expenditures distant from large debt maturities (and vice-versa) and setting collection dates of large revenues closer to these significant outflows. Potentially it is also possible to define a borrowing plan where issuance volumes are increased closer to the periods of expected low cash balances. However, it may not be practical and desirable given the regularity and predictability valued by investors on the debt issuance profile. Cash flow matching needs to be underpinned by strong cash flow forecasting and robust coordination between government entities (bottom-up approach).

The second way to minimize the cost of carry is to explore arrangements with the Central Bank for the remuneration of the cash balances deposited in the TSA, ideally at the market rates, as stated as a minimum requirement ${ }^{11}$ at DeMPA DPI 11.2. This second dimension of "Cash flow forecasting and cash balance management" DPI assesses the "decision of a proper cash balance (liquidity buffer) and effectiveness of managing this cash balance in government bank accounts". For countries being remunerated by the Central Bank, the conditions may significantly vary. Brazil, Colombia and Turkey have their cash balances remunerated by market interest rates ${ }^{12}$, while Peru and Bolivia do not (the latter receives remuneration linked to inflation). Chile and Slovenia use time deposits offered by the Central Bank and South Africa outsources the cash investment for the Corporation for Public Deposits, a subsidiary of the South African Reserve Bank.

There are also countries which deposit TSA cash balances in the Central Bank receiving no remuneration (Albania, The Gambia, Ghana, Honduras, Nigeria, Rwanda, Seychelles, Thailand and Uruguay). Some of them face legal restrictions and entered into agreements where there is a "compensation" represented by free-of-charge services provided by the Central bank for the Ministry of Finance, normally related to the TSA operational activities. Even in the cases where the Central Bank's profit is transferred to the Treasury (somehow compensating the lack of remuneration of TSA cash balances), a possible route might be to strengthen transparency through regulations to

11 Score C (minimum) requires that Issuance of short-term instruments is planned according to the forecast of monthly cash balances. In addition, the central government manages its surplus cash (that is, cash in excess of the target) through investment in the market in line with appropriate credit risk limits or with the central bank at market-related rates.

12 Even in those cases, countries still bear a cost of carry as they usually invest cash in shorter maturities than the ones used for debt issuance, and the yield curve commonly present a positive slope (meaning higher interest rates in the long end). 
enable the monetary authority to remunerate the TSA balances and on the other hand charge for its services, under an arrangement where proper cost allocation is clearer (Turkey adopted these measures in 2011).

Brazil has recently published a report on the relationship between the National Treasury and the Brazilian Central Bank $^{13}$ that sheds light on $\mathrm{CB}$ profit and losses composition and transfer framework, TSA structure and earnings, and CB treasury securities portfolio used for repo transactions. Pessoa and Williams (2012) present a thorough discussion about this relationship, which details are beyond the scope of this paper.

\section{B. Investing Cash Balances in the Market}

Besides the possibility of having TSA balances remunerated by the Central Bank, provided that prior conditions are in place, investing government cash balances in the market not only may lead to better remuneration, but also has the positive collateral effect of fostering the development of money and government securities markets, through the strengthening of price references. On the other hand, it creates counterpart credit risk to be accounted and monitored closely.

Coordination with the Central Bank is highly critical when investing the cash in the financial markets. The monetary authority welcomes information on cash flow forecasting, including planned short-term borrowing and investment resulting flows (that also affect the liquidity in the financial system). When sharing this information, cash managers mitigate the risk of competition with the Central Bank as it will carry out its monetary policy transactions taking into consideration government cash needs or excess of it. The coordination should ensure that the two government entities will not be unnecessarily at the same side of the market, competing for raise cash (drying-up liquidity) or invest it (injecting liquidity). Investing all the excess of cash in the market facilitates Central Bank's own cash flow forecast and liquidity management since all the government liquidity is re-injected immediately in the market.

Regarding investment instruments, cash managers may opt to use more than one (when available) to access different risk-return alternatives, according to investment time horizons and government risk appetite. The most common ones are illustrated in Figure 4 and their characteristics are described below.

Deposits: Commercial bank deposits are one of the fastest and easiest ways to invest cash, given that they are uncollateralized (no settlement system and margin calls ${ }^{14}$ are needed), do not have maturity dates as oppose to short-term instruments (possible automatic rollover) and tend to offer good remuneration compared to other alternatives. India, for instance, carries out auction of government cash balances to maximize the return. On the other hand, considering that the deposits are subject to the credit risk of the recipient banks and not backed by any asset in case of default, these are more commonly used only for overnight or very short-term tenure. Investing in multiple banks to diversify the risk can be good strategy, keeping in mind that it requires multiple credit risk assessment and permanent monitoring of all counterparties.

Government securities: Using the excess of cash to buy government securities is another widespread practice. Cash managers can either buy-back the government's own domestic bonds in the secondary market or invest in sovereign bonds of other countries (e.g. Slovenia). The latter is more usual for investment of liquidity buffers held in foreign currency, where investing in the US Treasuries is the most common practice, given its liquidity, low credit risk and denomination in USD. Countries such as France, Belgium, Netherlands and Germany set arrangements between them to do cash deposits with each other since there is no currency risk. These intercountry cash transactions may involve government securities as collateral.

Corporate bonds: It is less common to invest cash in corporate bonds, either issued by financial institutions (e.g. certificates of deposits) or companies (e.g. commercial papers, debentures). Given the low liquidity of these securities compared to government bonds, cash managers can either seek an early redemption option, or invest in a medium- to long-term horizon, targeting a better remuneration. Assessment and permanent monitoring of counterpart credit risk is also an outmost, which requires technical and human resources capacity. The UK is an example using certificate of deposits and commercial papers, although most of the liquidity is invested in reverserepo transactions.

13 https://sisweb.tesouro.gov.br/apex/f?p=2501:9::::9:P9 ID PUBLICACAO ANEXO:7 141

14. Provision of additional collateral when its price goes down 
Reverse repo: This is probably the most common investment instrument used by cash managers. Reverse repo transactions present comparative disadvantages to the other previously explored options but have one determinant advantage: it is backed by a collateral. Therefore, government gets exposure to the credit risk of the collateral issuer (most commonly itself) in lieu of the one associated to the transaction counterpart. The management of the collateral adds complexity (and cost) and the lower risk of this instrument results in lower remuneration. Given the strengthened credit risk, it is commonly used for longer periods, from few weeks to 1-3 months. The liquidity of the collateral, which is usually government securities, drives the liquidity risk assumed by the government in the transaction.

\section{Table 1}

Instruments used by selected countries for investing excess of cash

\begin{tabular}{|c|c|c|c|c|c|}
\hline & Central Bank deposits & Bank deposits & $\begin{array}{c}\text { Government } \\
\text { securities/buy-back }\end{array}$ & Other securities & Reverse-repo \\
\hline \multicolumn{6}{|l|}{ Albania } \\
\hline \multicolumn{6}{|l|}{ Brazil } \\
\hline \multicolumn{6}{|l|}{ Chile } \\
\hline \multicolumn{6}{|c|}{ Colombia } \\
\hline \multicolumn{6}{|c|}{\begin{tabular}{|l|} 
France \\
\end{tabular}} \\
\hline \multicolumn{6}{|c|}{ Hungary } \\
\hline \multicolumn{6}{|c|}{ India } \\
\hline \multicolumn{6}{|c|}{ Peru } \\
\hline \multicolumn{6}{|c|}{ Slovenia } \\
\hline \multicolumn{6}{|c|}{ Sweden } \\
\hline \multicolumn{6}{|c|}{ Turkey } \\
\hline \multicolumn{6}{|l|}{ UK } \\
\hline USA & & & & & \\
\hline
\end{tabular}

Note: Angola, Equatorial Guinea, Eswatini, The Gambia, Ghana, Honduras, Kosovo, Lesotho, Nigeria, North Macedonia, Romania, Rwanda, Seychelles, Thailand and Uruguay have not invested excess of cash in the market (reasons range from lack of capacity, lack of legal authorization or lack of idle cash).

Sources: Debt Management Offices/Agencies websites and countries presentations made in the WB Cash Flow Forecasting and Cash Management Workshops (2018 and 2019).

Countries experiences show that investing cash in the market is directly associated to the level of market development, in other words, availability of instruments, infrastructure and players. The deepening of domestic debt and money markets is a common objective of cash and debt managers, as well as of the CB and a medium-term plan to this end should be devised. Lienert (2019) offers an interesting approach on sequencing cash management reforms where active investment of cash balances comes in the later stages of the reforms, given supporting pillars needs to be built in earlier stages.

While debt management implementation is guided by the MTDS, when it comes to cash management, investments are driven by investment policies rather than strategies ${ }^{15}$. These policies take care of credit and liquidity risk management, commonly setting exposure limits to counterparts and instruments ${ }^{16}$. Table 3 shows an example from Chile.

$15 \quad$ Investment policies will define limits and conditions for the use of instruments, while debt strategies set directions for the government financing (possibly setting targets).

16 Buy-back can be an alternative to reduce cost of carry if the cost of new debt is lower than of the existing ones (and the differential higher than "other investments" remuneration), provided that there is an excess of cash to be invested/allocated. 


\section{Table 2}

Chilean Cash Management Investment Policy

\begin{tabular}{|c|c|c|c|c|}
\hline \multirow[t]{2}{*}{ Domestic Portfolio } & \multicolumn{3}{|c|}{ Asset class } & \multirow[b]{2}{*}{$\begin{array}{c}\text { Maximum limit } \\
\text { by instrument } \\
\text { (\% Domestic } \\
\text { Portfolio) }\end{array}$} \\
\hline & $\begin{array}{l}\text { Money Market } \\
\text { (Instruments } \\
\text { shorter than } 1 \text { year) }\end{array}$ & $\begin{array}{l}\text { Instruments } \\
\text { maturing from } \\
1 \text { to } 3 \text { years } \\
\text { (fixed-rate) }\end{array}$ & $\begin{array}{c}\text { Instruments } \\
\text { maturing from } 1 \\
\text { to } 3 \text { years } \\
\text { (inflation-linked) }\end{array}$ & \\
\hline \multicolumn{5}{|c|}{ Domestic Currency } \\
\hline Central Bank deposits & $x$ & & & $100 \%$ \\
\hline $\begin{array}{l}\text { Instruments issued by the } \\
\text { Central Bank }\end{array}$ & $x$ & $x$ & $x$ & $100 \%$ \\
\hline Reverse-repos & $x$ & & & $50 \%$ \\
\hline Commercial bank deposits & $x$ & $x$ & $x$ & $60 \%$ \\
\hline Short-term debt mutual funds & $x$ & & & $20 \%$ \\
\hline \multicolumn{5}{|c|}{ Foreign Currency (USD) } \\
\hline Central Bank deposits & $x$ & & & $100 \%$ \\
\hline $\begin{array}{l}\text { Instruments issued by the } \\
\text { Central Bank }\end{array}$ & $x$ & $x$ & & $100 \%$ \\
\hline Reverse-repos & $x$ & & & $50 \%$ \\
\hline Commercial bank deposits & $x$ & & & $45 \%$ \\
\hline $\begin{array}{c}\text { Maximum limit by asset class (\% } \\
\text { Domestic Portfolio) }\end{array}$ & $100 \%$ & \multicolumn{2}{|c|}{$20 \%$} & \\
\hline
\end{tabular}

\begin{tabular}{|c|c|c|c|c|}
\hline \multirow[t]{2}{*}{ International Portfolio } & \multicolumn{3}{|c|}{ Asset class } & \multirow[b]{2}{*}{$\begin{array}{c}\text { Maximum limit } \\
\text { by instrument } \\
\text { (\% International } \\
\text { Portfolio) }\end{array}$} \\
\hline & $\begin{array}{c}\text { Money Market } \\
\text { (Instruments } \\
\text { shorter than } 1 \text { year) }\end{array}$ & $\begin{array}{l}\text { Instruments } \\
\text { maturing from } \\
1 \text { to } 3 \text { years } \\
\text { (fixed-rate) }\end{array}$ & $\begin{array}{c}\text { Instruments } \\
\text { maturing from } 1 \\
\text { to } 3 \text { years } \\
\text { (inflation-linked) }\end{array}$ & \\
\hline \multicolumn{5}{|c|}{ Foreign Currency } \\
\hline Sovereign Bonds & $x$ & $x$ & $x$ & $100 \%$ \\
\hline Overnight investments & $x$ & & & \multirow{4}{*}{$50 \%$} \\
\hline Bank deposits & $x$ & & & \\
\hline Certificate of deposits & $x$ & & & \\
\hline $\begin{array}{l}\text { Short-term debt mutual funds } \\
\text { (Money Market Funds and ETFs) }\end{array}$ & $x$ & & & \\
\hline $\begin{array}{l}\text { Maximum limit by asset class (\% } \\
\text { International Portfolio) }\end{array}$ & $100 \%$ & \multicolumn{2}{|c|}{$20 \%$} & \\
\hline
\end{tabular}




\section{CONCLUSION AND KEY FINDINGS}

The Global Financial Crisis and the recent COVID-19 pandemic proved once again that efficient management of government's liquidity is crucial to respond to unanticipated revenue losses and increases in expenditures. Uncertain economic situation and unfavorable market conditions worsen the cash position, especially in countries with weak budget controls and poor cashflow forecasting. On the other hand, modern cash management provides tools to avoid delayed payments and accumulated arrears.

Country examples, based on experiences shared by practitioners WB workshops, and the findings of DeMPA assessments, indicate that full implementation of modern cash management is still a challenge. A TSA system is common in most countries, but further challenges remain. The strategy for building up liquidity buffers in many advanced and emerging countries give clues on the need for a hedge, due to the size of forecasting errors and volatility of cash flows. Possible renewed liquidity interruption in interbank markets also contributes for reviewing cash buffer policies. Therefore, cash flow forecasting is an area to improve in many developing countries, as shown in Figure 3 (DeMPA assessments) and in the low frequency of accuracy analysis made by countries who attended the workshops. Time horizon not shorter than the budget year, weekly/daily breakdown and updates constitute sound practices to be pursued, as adopted by Colombia, South Africa and Uruguay.

Coordination across institutions is vital for accurate cash flows forecasting. The analysis of country practices indicates that the coverage of cash flow projections, the horizon and frequency of forecasts are limited in many cases. To this end, consolidation of cash management functions in one unit, establishing a structured data/information collection framework, and setting up formal coordination mechanisms between cash management and budget, debt management and monetary policy implementation would be a good first step to improve the capacity to generate reliable and accurate cash flow projections.

When it comes to the use of instruments to cover cash shortages and investment of the excess of cash in the market (or with the Central Bank), challenges are even larger than on cash flow forecasting. As pointed out by DeMPA assessments (Figure 3) just $8 \%$ of 80 assessed lower income countries get a minimum score or above at DPI 11.2 (cash management), and in 3 out of the 5 regions none of the countries reached this minimum. The connection between cash flow forecasting and the issuance of T-Bills can be strengthened and made clearer and more transparent in some countries. However, investment of the idle cash seems to be a rather bigger weakness, with many countries placing their liquidity buffers in the Central Bank with no remuneration.

Cash managers can cover temporary cash shortages using multiple instruments that fits better to different needs in terms of time horizon and risk appetite. However, most of the assessed developing countries solely rely on the issuance of T-Bills and do not use repo transactions, mostly because they have underdeveloped money markets, lacking legal framework, and collateral liquidity concerns in case of counterparty default ${ }^{17}$. On the other hand, intra-government borrowing which has been increasingly used by emerging market economies, (Colombia, Peru and South Africa) might be an option for the countries where the government bond markets are less developed.

The active investment of cash balances in the markets is incipient or inexistent not only in low-income countries, but also on different income level countries listed in the introduction. Out of the 24 countries that participated in the WB cash management workshops, only Albania, Bolivia (offshore), Chile, Colombia, Peru, Slovenia and South Africa claimed to invest their surplus balances in the market. Weak cash flow forecasting, no formally defined liquidity buffer and underdeveloped money market are the main reasons explaining this gap.

To conclude, country experiences indicate a significant room for short-term improvements in all aspects of cash management including the accuracy of cash flow projections, efficient use of funding instruments for temporary cash shortages, and investment of TSA balances to reduce the cost of carry. To this end, strengthening the technical capacity in cash management, improving the governance structure and the coordination with fiscal, debt and monetary policy enable governments to better manage liquidity and cope with stress situations as proven once more in Covid-19 pandemic.

17 None of the 24 participant countries in the WB Cash Flow Forecasting and Cash Management workshops use repo transactions to cover cash shortages. 


\section{REFERENCES}

Agence France Tresor, Managing Government Cash Flows - Performance, https://www.aft.gouv.fr/en/cashmanagement- performance and Debt Management - General Information - Products, https://www.aft.gouv.fr/ en/products- Accessed on May 22nd, 2020

Agência de Gestão da Tesouraria e da Dívida Pública - IGCP, Home Page, https://www.igcp.pt/en/ Accessed May 22 nd, 2020

Arslan, Y, Drehmann, M and Hoffmann, B “Central bank bond purchases in emerging market economies” BIS Bulletin No 20, June 2020

AKK, Annual Reports, https://www.akk.hu/en/page/ publications\#annual-reports Accessed on May 22nd, 2020

Cangoz, M.C., S. Boitreaud, and C. Dychala (2018) "How Do Countries Use an Asset and Liability Management Approach?” Policy Research Working Paper 8624, The World Bank

Cashin, C., S.Sparkes and D. Bloom (2017) "Earmarking for Health: From Theory to Practice" Health Financing Working Paper, WHO

Cruz, P. and F. Koc (2018) “The liquidity buffer practices of public debt managers in OECD countries" OECD Working Papers on Sovereign Borrowing and Public Debt Management No:9

Department of Economic Affairs of India, Public Debt Management, https://www.dea.gov.in/public-debtmanagement, Accessed on May 22nd, 2020

Jácome, L., Matamoros-Indorf, M., Sharma, M. and Townsend, S. (2012) "Central Bank Credit to the Government: What Can We Learn from International Practices?” IMF Working Papers 12/16

Investor Relations of Colombia, Publications - Documents of Interest http://www.irc.gov.co/webcenter/portal/ IRCEs/pages_Publicaciones/documentosdeinters Accessed on May 22nd, 2020

IMF (2020) "Fiscal Monitor" https://www.imf.org/en/ Publications/FM/Issues/2020/04/06/fiscal-monitorapril-2020 Accessed on June 18, 2020

Lienert, I. (2009) “Modernizing Cash Management” Technical Notes and Manuals, International Monetary Fund

Miller, M. and S. Hadley (2016) "Cash management in cash- constrained environments" Overseas Development Institute

Ministry of Finance of Brazil, National Treasury, https:// sisweb.tesouro.gov.br/apex/f?p=2501:9::::9:P9_ID_ PUBLICACAO_ANEXO:7141 Accessed on July 1st, 2020

Ministry of Finance of Chile, Investor Relations, https://www. hacienda.cl/english/investor-relations-office/ presentations. html Accessed on May 22nd, 2020

Ministry of Economy and Finance of Peru, Public Debt https://www.mef.gob.pe/es/deuda-publica-sp-14826, and Financial Policy Guidelines https://www.mef.gob.pe/en/ financial-strategy Accessed on May 22nd, 2020

Ministry of Treasury and Finance of Turkey, Public Debt Management Report, https://en.hmb.gov.tr/public-debtmanagement-reports Accessed on May 22nd, 2020

National Treasury of South Africa, Investor Relations, http:// investor.treasury.gov.za Accessed on May 22nd, 2020

Pattanayak, S. and I. Fainboim (2011) "Treasury Single Account: An Essential Tool for Government Cash Management" Technical Notes and Manuals, International Monetary Fund

Pessoa, M. and Williams, M (2012) "Government Cash Management: Relationship between the Treasury and the Central Bank" Technical Notes and Manuals, International Monetary Fund

Storkey, I. (2001) "International Government Cash Management Practices" www.storkeyandco.com accessed on August 22, 2020

Swedish National Debt Office, About the Debt Office, https:// www.riksgalden.se/en/About-the-Debt-Office/ Accessed on May 22nd, 2020 
World Bank, Finance, Competitive and Innovation (FCI) - https://dataviz.worldbank.org/views/FS-COVID19/Overv iew?:embed=y\&:isGuestRedirectFromVizportal=y\&:displ ay_count=n\&:showAppBanner=false\&:origin=viz share_link\&:showVizHome $=$ n

Williams, M. (2004) “Government Cash Management: Good and Bad Practice” http://www.mj-w.net/cac_gov_cash. html accessed on August 22, 2020

Williams, M. (2010) “Government Cash Management: Its Interaction with Other Financial Policies” Technical Notes and Manuals, International Monetary Fund 